\title{
SUGGESTIONS ON AN EDITORIAL GUIDELINE FOR THE LATIN LANGUAGE PEACE TREATIES BETWEEN THE HABSBURG AND THE OTTOMAN EMPIRE BASED ON THE $18^{\text {TH}_{-}-\mathrm{CENTURY} \text { CASE STUDY }}{ }^{1}$
}

\section{Gergely Brandl}

http://orcid.org/0000-0002-6958-0571

University of Szeged (Hungary) Szentgyörgyi Albert Medical School, Department for Medical Communications and Translation Studies

MTA-SZTE Research Group of the Ottoman Age (ELKH), Szeged (Hungary)

\begin{abstract}
The aim of the paper is to provide a conceptual and theoretical framework for transcription of Latin historical texts based on the case study of the peace treaty of Passarowitz (1718). The article discusses some of the major works on editing Latin source publications concerning the scripts originating from the territories of the Hungarian kingdom. The paper attempts to provide answers for two major questions. Firstly, why should a specific sample-based guideline be elaborated on in case of the Ottoman-Habsburg Latin peace treaty documents and secondly, how should it be done. In accordance with that, the paper presents a sample guideline in the appendix, with transcriptional examples for the most of the relevant problems, covering the issues of transcription, editorial apparatus, problems of translation and indexing as well.
\end{abstract}

Keywords: Ottoman-Habsburg peace treaties, palaeography, Latin editorial guideline, transcription, diplomatic history, treaty of Passarowitz.

${ }^{1}$ The present study was founded by the Ministry of Innovation and Technology (Innovációs és Technológiai Minisztérium) through the grant of the New Hungarian National Excellence Program (Új Nemzeti Kiválóság Program) (code no. ÚNKP.19-3STE-33). This paper is written as a contribution of the Interdisciplinary Centre of Excellence, the Department of Medieval and Early Modern Hungarian History (Faculty of Humanities and Social Sciences) (University of Szeged), and the MTA-SZTE Research Group of the Ottoman Age. I should thank for the special help of Eszter Ótott-Kovács (Cornell University), Gábor Petneházi (University of Szeged) and László Glück (Hungarian Academy of Sciences) who helped me with their special remarks. I should thank also for the help of the MTA-SZTE Research Group of the Ottoman Age. Especially for Péter Bara, who let me use his unpublished manuscript on transcriptional suggestions. 


\section{INTRODUCTION AND THE AIMS OF THE DISCUSSION PAPER}

The major aim of the present paper is to give general remarks in order to elaborate a guideline to publish Latin language historical texts within the framework of the project of the MTA-SZTE Research Group of the Ottoman Age. ${ }^{2}$ It seems inevitable that an editorial guideline (framework for publication) would be the basis for various monographs even in different source languages. Therefore, it should be harmonised with the source publication guidelines and apparatus of other languages. Accordingly, this article can be considered as a discussion paper, which intends to join the old historical tradition of opening debates. Since many of the latter major book series has published demonstrative chapters, that let experienced scholars share their knowledge in due time of preparing elaborate works. This cooperative endeavour may seem necessary even more, since the time span of the survey expands from the $14^{\text {th }}$ to $18^{\text {th }}$ century and the source material is varied not only by thematical means but also in case of textological and palaeographical attributions, even if the major part of them relates to diplomatic history. Moreover, significant alterations can be found in the linguistic and editorial customs, even in case of one language. ${ }^{3}$ All the more so, since translations of texts with nearly the same content are often discussed and implemented, text variants or vernacular language expressions are also common in the discussed scripts.

However, the wide perspective can be deceptive, as the present study is focused on the Habsburg-Ottoman peace treaties, which raise very specific concerns. ${ }^{4}$ These include the intercultural aspects of the peace making process or the examination of contemporary translation techniques. So, issue of the relative identicality (equivalence of the content of the scripts) of the treaties has been the subject of considerable debates in their own time as well. Furthermore, we should tackle with the issue of merging conceptual frameworks in different languages and through various cultural, religious, etc. concerns (e.g. Muslim and Christian legal terminology), especially when one should translate, transform, and localise them in foreign languages. Moreover, the diverging traditional practice of issuing documents by various authorities (e.g. the Habsburg and Ottoman chancellery) can mean impediment to our survey as well. Not to mention that this is a period prior to the consolidation of international law. Consequently, the rules of international relations were generally conducted by

2 About the main goals of the research group, see: S. Papp, "Az Oszmán Birodalom, a Magyar Királyság és a Habsburg Monarchia kapcsolattörténete a békekötések tükrében (vázlat és adatbázis)," $A e$ tas 2018, no. 4, pp. 86-99; G. Brand1, Cs. Göncö1, K. Juhász, G.E. Marton, J. Szabados, "Válogatott források az 1627. évi szőnyi békeszerződés történetéhez," Lymbus 2017, no. 1, pp. 153-203 (especially see: pp. 153-154). To the description of the Research Group's project, see: http://hist.bibl.u-szeged. hu/mta-szte/kutatocsoport/ [access: September 30, 2019].

3 About the sources of the peace treaties, see: G. Brand1, Cs. Göncöl, K. Juhász, G.E. Marton, J. Szaba dos, "Kommunikáció és híráramlás az 1627. évi szőnyi békekötés alkalmával a Habsburg oldal tárgyalási stratégiájának tükrében,” Aetas 2018, no. 4, pp. 108-124.

4 On the sources of one specific negotiations with a similar insight, see the earlier note and also: G. Brand1, Cs. Göncöl, K. Juhász, G.E. Marton, J. Szabados, "Válogatott források," pp. 151-203. 
respecting traditions or by customary manners. Or even this is exactly the time when the framework of these political relations was settled.

Especially these difficulties can be seen as justifications for case studies. It may seem valid, based on the source material and time span, that the examination of the subject is shifting towards the methodological approaches of the so-called "longue durée," however, we must initially deal with each negotiation on a case-by-case basis, even if distinguished common traditions have been developed (e.g. ceremonial change of envoys, customary textual turns in documents). ${ }^{5}$ Since the periods before the battle of Mohács, during the Ottoman oppression and after the reconquest of Hungary generally differ in the relationship to the Turks, though the negotiations are very much affected by the earlier traditions. Therefore, case studies need to be done of different periods with distinct legislative and ceremonial traditions for comparison.

For the purpose of this case study, we have selected the ratified documents of the peace treaty of Passarowitz from the $18^{\text {th }}$ century. This choice also restricts our viewpoint, since the text come from a period of a much clearer secretarial practice of the issuing authorities and when the negotiations had a ceremonially more clarified and elaborated methods. It is attempted to eliminate the effects of this narrower viewpoint by selecting diverse examples, tough it still strongly influences the orientation of the editorial guidelines. This raises the question that, to what extent can be such a set of suggestions considered universally applicable for different source editions. One may firmly believe that the apparatus can be applied in case of various texts, even if alteration would be needed (mostly because of the linguistic specificities). Thus, in case of non-diplomatic or in linguistically non-standardised texts this editorial guideline can be considered a point of reference. ${ }^{6}$

Besides, one cannot leave the questions of the digital text publishing untouched. Although we are primarily thinking of a paper-based edition of the Habsburg-Ottoman peace treaties, there is also a need for an editorial and transcriptional framework for digital publishing which can be almost similar. At the same time, as for the appendices and indices, there is a certain need to have a format which can be easily adjusted to the criteria of digital databases. Therefore, it might contain the notions to be explained independently of the philological notes in unified a scheme. Also, due to the large amount of text, digital publishing will be inevitable in the future, making

About the general questions of peace making with the Ottomans, see: E.D. Petritsch, "Dissimulieren in den habsburgisch-osmanischen Friedens- und Waffenstillstandsvertragen (16-17. Jahrhundert): Differenzen und Divergenzen" [in:] Frieden und Konfliktmanagement in interkulturellen Räumen: das Osmanische Reich und die Habsburgermonarchie in der Frühen Neuzeit, eds. A. Strohmeyer, N. Spannenberger, Stuttgart 2013, pp. 145-162; A. Strohmeyer, "Wahrnehmungen des Fremden: Differenzierungen von Diplomaten im 16. und 17. Jahrhundert: Forschungsstand - Eträge - Perspektiven" [in:] Wahrnehmungen des Fremden: Differenzierungen von Diplomaten im 16. und 17. Jahrhundert. (Schriftreihe der Vereinigung zur Erforschung der Neueren Geschichte. e. V., 31.), eds. M. Rohrschneider, A. Strohmeyer, Münster 2007, pp. 1-50.

6 The latest research about the texts, document and history of the peace treaty of Passarowitz, see: S. Papp, “A pozsareváci békekötés és a magyarok,” Aetas 2018, no. 4, pp. 5-19. 
the created corpus easier to access and search. ${ }^{7}$ All the more so, since scholars dealing with neo-Latin source publications (mainly in case of literature) have already started projects aiming to build on-line databases. ${ }^{8}$

Finally, after the acquiring the source material, one need to lay down the practical principles for the publication, whereas numerous scholars should cooperate in a respectively uniformed framework representing various source material in diverse languages from different eras. Based on that, the most important goal is to contribute to the discussion on a uniformly operating editorial framework in order to solve issues that may arise in practice.

\section{PROBLEMS IN CRITICAL EDITION AND THE QUESTION OF A SAMPLE GUIDELINE}

The well-established tradition for historical publications is to create more and more self-employed research policies for various eras or thematical schemes, which rely on the previous well-received editorial guides (e.g. the editorial rules of the Hungarian Academy of Sciences from 1920). When creating this guideline, one must attempt to avoid presenting his studies as novel achievements in an unknown field. Rather, we strive to build on the results accumulated previously to create a pragmatic framework that can be adapted to the current circumstances, which, after debates, discussions and experimental transcriptions can be an initial material. ${ }^{9}$

Although, in case of the broader subject (early modern diplomatic history) a large variety of documents can be available, yet we are currently focusing on bilateral and multilateral peace treaties. The peculiarity of these is that the texts have a relatively similar content, but due to the different types and forms of the charters and files, one might consider copies issued and authenticated in different manners, and written in different languages, which originate from different eras. On the basis of that, publishing according to unified rules, every editor automatically encounters problems of modernisation and unification, which are all the more difficult to overcome as the documents of these treaties are often copied and have a very diverse genealogical tradition which barely discussed or treated as evidence. At the same time, these texts became well-known in often poorly referenced but traditionally published editions, and often the latter historiography only knew these texts copied from one another,

\footnotetext{
7 About the problems of database building referring to digital editions, see: G. Brandl, Cs. Göncöl, K. Juhász, G.E. Marton, J. Szabados, “Kommunikáció és híráramlás,” pp. 108-124.

8 Among the neo-Latin database, the Digital Neo-Latin library is outstanding. About the project and on the topic of building of Latin text databases, see: https://digitallatin.org/about-project [access: September 30, 2019].

9 The most significant previous Hungarian scientific editorial and publishing guidelines for historians are collected in one place, as well as the editorial guideline of the Hungarian Academy of Sciences (1920) and the related book series, see: "Forrráskiadási szabályzatok (újraközlések)," Studium Füzetek 2000, no. 1, for the discussed period see: pp. 5-127.
} 
almost forgetting their more authentic copies. Not to mention the most impedimental circumstance that the final ratified documents of the treaties because of the mutual authentication of the definite files were changed between the two imperial capitals. However, the copies reserved in Vienna mostly remained (and their investigation can be carried out effortlessly), yet the version would have been kept in Constantinople (present day Istanbul in Turkey) are missing. Therefore, the ratified Latin versions cannot be found in original authentic versions. Although the originals are missing, in most of the cases philological and archival research can reveal different variants and based on these manuscripts and contemporary copies the original text can be restored. Moreover, these copies are mostly available in both issuing languages and, in many cases, even in languages of mediating states (e.g. English, Dutch) or languages used by different commissaries of the negotiating realms (e.g. Italian).

Returning to the question of modernisation which was posed at the beginning of this study, according to which one may focus on the feasibility of our editorial guideline and therefore the general aim is to prepare a framework for a full-text edition in the original language for broad usage. Due to the significant historical value of these documents, these texts may be used generally in further studies. Consequently, we might not implement the main text of our edition excessively and keep the text "clean;" therefore considering the various philological and/or contextual observations in endnotes and footnotes and in different parts of the apparatus. It is these aspects that make translations crucial, as only modern translations can make these texts accessible even to those readers who are not familiar with the actual source language or even to international scholars. It is an obvious decision in Latin transcription to rely on humanist Latin forms, making the issue of unification much easier to accomplish. Even more so, since in the humanist era of the neo-Latin language, one can claim that Latin is a standardised language. As a result of this "uniformed" appearance, some of the existing national editorial guidelines even settle editorial questions in just a few lines. ${ }^{10}$ The standardisation is also underlined by the fact that extensive number of variants is accessible in case of Latin treaties (e.g. drafts, excerpts, translations, partial copies, etc.).

However, in certain cases, multiple versions are available, but because of identicality or marginal relevance of the variants of texts, not all of them need to be published, still a philological framework can be created to arrange the different manuscripts. Consequently, the selection of the documents has an important role and it is necessary to decide regarding what aspects we designate the primary manuscripts, since these documents can be considered as substantial due to their function in the international relations. Additionally, most of these files already have numerous publications and are commonly cited in historical works.

Therefore, it is worth to describe the attributions of our basic scripts. The ideal primary manuscript would be a ratified, corroborated and authenticated version of the

10 The suggested editorial rules of the Austrian Academy of Sciences give us firm example for it. See: "Empfehlungen zur Edition frühneuzeitlicher Texte," Jahrbuch der historischen Forschung in der Bundesrepublik Deutschland 1980, pp. 85-96. It is cited by I. Fazekas, "Korreferátum Oborni Teréz elöadásához," Fons 2000, no. 1, pp. 77-80. 
finalised charter, which would be issued in an ornamented form and has been mutually recognised in its content. Unfortunately, (as we have mentioned above) due to the mutual exchange of documents the Habsburgs' copies (Latin original documents) had been sent to Constantinople and presumably destroyed. By reason of that, one might consider the enunciated texts of declarations, finalised drafts of negotiators, or copies of ambassadors and envoys as the primary text for editions. Regarding these, those manuscripts can be seen as primary texts which come closest to the final edition of the eventual charter from the period of the negotiations or from the time of the ratification process. These kind of scripts may generally be found in the depositories of the central archives of the Habsburg Empire in Vienna (e.g. Österreichisches Staatsarchiv Haus- Hof- und Staatsarchiv, Türkei I, in the following: ÖStA HHStA, Türkei I) or possibly in archives of aristocratic families due to the personal inheritance or correspondences of diplomatic personnel having the role of ambassador or commissioner during the peace making process. In rare cases the deficiency of the complete text emerges even so, but the deficit can be substituted by copies already published in print (e.g. leaflets, newspapers, etc.). Consequently, the absence of original versions of the charters often poses obstacles concerning the ratification process and the declaration part of the documents (corroboration). All the more so, the common formulas for declaration or external characteristics of the charter cannot be found in documents prepared during the negotiations for use of political discussions. However, this matter of fragmented documents can be solved by means of supplementing the texts from the enrolled various sources. All in all, it may seem arguable that we publish only the texts considered primary and the lineage and genealogy of the manuscripts together with the debatable issues of the various scripts would be discussed in a preliminary study of each peace treaty. Also, duplicates or draft copies (unless they contain significant differences) are marked only by archival references.

One may also tackle with the issues raised by the previous editions and scientific literature, since, it is conceivable that only the relevant editions should be mentioned. Ergo, only those which cites the authentic manuscript or relevant archival sources concerning the text of the treaty itself. Others, which are copying or reprinting the already used studies, are not referred to as bibliographical sources. Collecting them would understandably stretch the frames, as it is not the purpose of this study to reveal the reception history of previous text editions. ${ }^{11}$

The purpose of the present study is to facilitate a moderate, clean and plain publication of the texts in a modern format for a wider audience. Simultaneously, it attempts to be appropriate regarding the scholarly sophistication awoke by historical endeavours with its philological apparatus, though it would not attempt to achieve the goals of linguistic survey or literary studies. Because of practical use of the editions, the translations also tend to focus more on modern language models, and as for aiming to give content based feasible translations. In addition to translations, we intend

11 The catalogue of the different peace treaties has been complied by Sándor Papp. The article as a database contains the archival and historiographical references as well, due to what one may have an insight into the complexity of methodological and research problems. S. Papp, "Az Oszmán Birodalom," pp. 86-99. 
to provide the text with abstracts and detailed indexes, hopefully serving the needs of a wide readership while meeting the high standards of scientific usability.

\section{ON THE HISTORICAL LITERATURE OF THE TOPIC: MODELS IN THE $18^{\mathrm{TH}}$-CENTURY STUDIES}

The history of Latin writing, textology, palaeography, etc. can be considered independent research fields and they also have inner historiographical approaches. It is not the purpose of this study to present new scientific results in these fields or even evaluate the various achievements. Due these practical constraints, this paper cannot provide a comprehensive review of literature on Latin text editing, it highlights some significant studies or feasible examples among the Hungarian studies concerning the topic.

According to overall synthesis, the international manuals are valuable of which many new encyclopaedic summaries are available for questions of the neo-Latin literary and linguistic environment. ${ }^{12}$ In addition, we have excellent handbooks to describe the domestic Latinity as well. ${ }^{13}$ However, a comprehensive dictionary of the Latin language used in the Kingdom of Hungary is not yet entirely attainable, ${ }^{14}$ notwithstanding to that the previous universal dictionaries and numerous smaller thematic glossaries are available as well. ${ }^{15}$ At the same time, the larger text editions have all adapted the earlier text publishing traditions. ${ }^{16}$ Not surprisingly, among the editorial guidelines and style sheets the ones shaped by the Hungarian Academy of

12 For example, see: P. Ford, J. Bloemendal, F. Ch. Fantazzi, Brill's Encyclopaedia of the Neo-Latin World, Leiden 2014.

13 The monographic work of Zsigmond Jako is the most significant handbook in the Hungarian historiography to describe the linguistic and palaeographical specificities for the Latin language, especially for language used in the Kingdom of Hungary, see: Zs. Jakó, R. Manulescu, A latin írás története, Budapest 1987.

14 The dictionary extended till the ' $m$ ' letter, see: J. Harmatta, K. Szovák, I. Boronkai, L. Benkő, I. Bellus (eds.), Lexicon Latinitatis Medii Aevi Hungariae I-VI, Budapest 1982-2017.

${ }_{15}$ H. Finály, A latin nyelv szótára, Budapest 1884; A. Bartal, A magyarországi latinság szótára, Budapest 1901; I. Szamota, Gy. Zolnay, Magyar oklevél-szótár, Budapest 1902-1906. In details, see: L. Gáldi, Magyar szótárirodalom a felvilágosodás korában és a reformkorban, Budapest 1957.

16 About the history of the Hungarian source publishing and historical text editing, see: B. Hóman, A forráskutatás és a forráskritika története, Budapest 1925; K. B enda, "A magyar történeti forráskiadás múltja és mai helyzete. I. rész," Levéltári Közlemények 1979, no. 2, pp. 163-173; eadem, "A magyar történeti forráskiadás múltja és mai helyzete. II. rész,” Levéltári Közlemények 1982, no. 2, pp. $201-$ 205; eadem, A történeti forráskiadványok helyzete Magyarországon, Levéltár és nyilvánosság. Levéltári Napok 1992, Budapest 1993, pp. 7-18; Z. Horváth, "Editio Multiplex - Kora újkori források kiadása" [in:] Docere et movere: Bölcsészet- és társadalomtudományi tanulmányok a Miskolci Egyetem Bölcsészettudományi Kar 20 éves jubileumára, eds. M. I. Kovács, É. Gyulai, T. Porkoláb, G. Biczó, Miskolc 2012, pp. 163-174. The most extended survey of the topic is given by the bibliographical works of Kosáry (and his latest team), even so the general part (latest two volume of the series) cannot be considered complete. Especially: D. Kosáry, K. Kulcsár, O. Szakály, Bevezetés Magyarország 
Sciences are stand. A great illustration for that is the most recent set of instructions for the book series of the Institute for Literary Studies, ${ }^{17}$ or the previous regulation for source criticism compiled by László Péter. ${ }^{18}$ Accordingly, among the historical source editions the suggestions of the Academy were also in general use, ${ }^{19}$ which were partially supplemented in the novel editorial recommendations published in the thematical issue of the Fons journal, based on a conference held in the Hungarian Academy of Sciences. ${ }^{20}$

Other disciplines were also eminent in source publishing spanning over long periods. Of these, it is worth using the long going publications of Hungarian witchcraft trials, which started as a common endeavour for ethnographic, legal and historical investigations, whereas a great deal of practical experience has been accumulated, covering almost the entire territory of the country, publishing city, county and central administrative sources, and made available diverse types of documents over a period of 400 years. ${ }^{21}$ Of course, many historical and archival publications could be listed, since most historical publications have their own editorial rules. In this way, a series of edition can be highlighted of $18^{\text {th }}$-century ornamented accrediting charters, which was edited by István Soós. ${ }^{22}$ Particularly relevant to note are the surveys of Gergely Tóth related to the works of Matthias Belius (Mátyás Bél), since he has done exemplary work with his colleagues on arranging and exploring manuscripts and as well

történetének forrásaiba és irodalmába I. Általános rész, 3. köt., Megyei levéltárak és forrásközlések, Általános rész 4. köt., Városi, mezővárosi és községi levéltárak és forrásközlések, Budapest 2008-2015.

17 Hungarian Academy of Sciences Research Centre for the Humanities (in the following: HAS $\mathrm{RCH}$ ) Institute for Literary Studies. S. Bene, E. Békés, "Módszertani ajánlás a Bibliotheca Scriptorum Medii Recentisque Aevorum új sorozatának (Series Nova) szöveggondozásához," Irodalomtörténeti Közlemények 2014, no. 1, pp. 698-713.

18 L. Péter (ed.), Irodalmi szövegek kritikai kiadásának szabályzata, Budapest 1988. (Its appendix contains rules for publishing of $16^{\text {th }}-19^{\text {th }}$-century foreign language texts. Latin, pp. 88-89; French, pp. 89-90; Italian, p. 90; German, p. 91; the part for the Latin language was written by P. Kulcsár).

19 The editorial guideline of the Hungarian Historical Society, Századok 1920-1921, no. 1, pp. 1-24; K. Benda, "A Magyar Országgyűlési Emlékek sorozat 1607-1790 közti részének szerkesztési és forrásközlési szabályzata,” Századok 1974, no. 2, pp. 436-475.

20 A special issue of the Fons periodical were entitled for source publishing questions, see: Fons 2000 , no. 1. Important articles and discussion papers of this issue which dealt with the problems of a Latin historical guideline, see: I. Tringli, Középkori oklevelek kiadásának problémái, pp. 7-40; T. Oborni, A kora újkori latin nyelvü forrásszövegek kiadásáról, pp. 67-75; I. Soós, Javaslatok az újkori magyarországi latin és német nyelvü források kiadására, pp. 81-89.

${ }^{21}$ About the processes conducted on the county's court sessions, see: J. Bes senyei, A. Kiss, S. PálAntal, P.G. Tóth, A magyarországi boszorkányság forrásai I-IV, Budapest 1997-2005. And processes conducted in cities, see: B. Balogh, Nagybányai boszorkányperek, Budapest 1997; E. Hagenthum, Segesvári boszorkányperek, Budapest 2010; P.G. Tóth, I. Németh, Soproni boszorkányperek, Budapest 2010; P.G. Tóth, L. Pakó, A. Kiss, Kolozsvári boszorkányperek 1564-1743, Budapest 2014; G. Brand1, P.G. Tóth, Szegedi boszorkányperek 1726-1744, Budapest 2016 (Nagybánya present day is Baia Mare, Segesvár present day is Sighişoara, Kolozsvár present day is Cluj-Napoca in Romania - G.B.).

${ }^{22}$ For the ornated, crested charters and diplomas of the Kingdom of Hungay in the $18^{\text {th }}$ and $19^{\text {th }}$ century, see e.g.: I. Csáky, Esztergom vármegye címereslevele, Nyíregyháza 2011; or for the ecclesiastic charters from the $18^{\text {th }}$ and $19^{\text {th }}$ century, see: I. So ós, VI. (III.) Károly német-római császár, magyar és cseh király adománylevele a szentgotthárdi ciszterci apátság visszaállitásáról és a heiligenkreuzi ciszterci apátsággal történö egyesitéséröl, 1734, Szentgotthárd 2016. 
in case of editing and publishing them. ${ }^{23}$ In addition, we used two unpublished manuscripts from the Institute of History of the Hungarian Academy of Sciences, ${ }^{24}$ which were prepared by László Glück and Péter Bara for the publication of historical texts. ${ }^{25}$

At last, but with an outmost importance, one should mention the works of researchers of the Ottoman Empire, who have set examples even for the Latin language source publications. Mainly because they have already published diplomatic documents with nearly the same content in relation with the Ottoman Empire. It is essential to refer to the works of Dariusz Kołodziejczyk according to the PolishLithuanian and Ottoman relationship with a special role to the Crimean Tatars, ${ }^{26}$ since he published the texts of the peace treaties between the frequently opposed parties. ${ }^{27}$ Moreover, it is also worth to mention the work of Hans Peter Theunissen, who published an influential volume on various Venetian-Ottoman treaties and contracts. ${ }^{28}$ And last but not least, we should underline Sándor Papp's monograph, who published some of the most relevant documents according to the Hungarian-Transylvanian and Ottoman diplomatic relations, especially contracts (known as Ahd-names) related to the vassal state of Transylvania. ${ }^{29}$ These critical editions contributed to our work by pointing out such issues as the problematic issue of modernisation of toponyms or the usage of intertextual notes.

${ }^{23}$ Gergely Tóth in his PhD dissertation (G. Tóth, Bél Mátyás „Notitia Hungariae novae...” címü müvének keletkezéstörténete és kéziratainak ismertetése, (manuscript), Budapest 2007, See: Eötvös Loránd University Budapest, Faculty of Humanities http://doktori.btk.elte.hu/hist/tothgergely/diss.pdf [access: February 5, 2020]. In later papers he analysed the different manuscripts and the editorial history of Matthias Bél's Notitia. In his works he has set up an analytical system through which the different hands and co-workers of Bél's and fellow writers could be explored, in line with the various copies etc. of the famous work. Based on his studies he established a research group where an extended publication and research into the textology, philology, etc. into Bél's work is conducted. From many aspects their work can be considered exemplary. About the group and their source publications, see: B. Mihalik, "Bél Mátyás Notitiájának kiadása - a forráskiadás 21. századi útjai," Történelmi Szemle 2013, no. 2, pp. 341-349.

24 HAS RCH Institute of History.

25 See: L. Glück, Latin szövegkiadási szabályok (manuscript), Budapest 2017; P. Bara, Latin szövegek átírása és jegyzetelése (tervezet), (manuscript), Szeged 2018.

${ }_{26}$ The Crimean Khanate can be considered as an Ottoman vassal state in the given period $\left(17^{\text {th }}-18^{\text {th }}\right.$ century).

${ }^{27}$ His work on Polish-Ottoman relations, see: D. Kołodziejczyk, Ottoman-Polish Diplomatic Relations (1 $15^{\text {th }}-18^{\text {th }}$ Century). An Annotated Edition of 'Ahdnames and Other Documents, Boston-Köln 2000. According to peace treaties, see: idem, The Crimean Khanate and Poland-Lithuania. International Diplomacy on the European Periphery $\left(15^{\text {th }}-18^{\text {th }}\right.$ Century). A Study of Peace Treaties Followed by Annotated Documents, Boston 2011.

28 H.P.A. Theunissen, "Ottoman Venetian Diplomatics: the 'Ahd-names. The Historical Background and the Development of a Category of Political-Commercial Instruments together with an Annotated Edition of Corpus of Relevant Documents," Electronic Journal of Oriental Studies 1998, no. 2, pp. 1-698.

${ }_{29}$ The work of Sándor Papp on the Ottoman documents and charters Hungarian and TransylvanianOttomn relations, see: S. Papp, Die Verleihungs-, Bekräftigungs- und Vertragsurkunden der Osmanen für Ungarn und Siebenbürgen. Eine quellenkritische Untersuchung, Wien 2003. 


\section{APPENDIX: SUGGESTIONS FOR A COMPLETE EDITORIAL GUIDELINE FOR PUBLISHING OTTOMAN-HABSBURG PEACE TREATIES}

\section{Transcriptional changes (orthographic and spelling problems)}

The transcription of the Latin texts diverges from the original orthographic form and shifts towards a so-called "humanist" version. The main reason is the historical nature of the edition, therefore the linguistic and literary issues may be overshadowed by the historical practicality. Moreover, one might consider the fact that the body of the text spans over a long period of time, consequently, numerous different publishing traditions need to be managed simultaneously. However, it seems that most texts tend to follow the humanist orthographic tradition. All in all, in order to have a unified appearance, it may be worth using handbooks as references and models in case of scripts originating from Hungarian territories, as well as for forms of Slavic and Hungarian loanwords. ${ }^{30}$ So as vantage points, we have chosen a general dictionary, which can be considered to be a unified standard language form. ${ }^{31}$

\section{Transcription of special symbols}

The ' $-\ddot{y}$-' should be transcribed as '- $i i-$ ', excluding proper names, in which only the diacritical signs should be deleted (e.g. "provincÿs" = provinciis, but "Michael Czacky" = Michael Czacky). ${ }^{32}$ Special symbols that represent ligatures and diphthongs should be written independently, so '-ce-' becomes '-ae-' (e.g. "publicandce" = publicandaei) and '-oe-' should be used instead of '-oe-' ("ponis" = poenis). We transcribe the '- $\ddot{w}-$ ' as ' $-w-$ ' or as ' $-v-$ ', but not in proper names, where it loses only the diacritic ' $-w$-'. The same holds for adjectives derived from proper names (e.g. "ẅaradiensis" = Waradiensis, but "wero" = vero).

\section{Letters, characters, etc. not in use in the humanist orthography}

The ' $k$-' letter always becomes ' $-c$ '' in the transcription (e.g. "artikulus" $=a r$ ticulus). The '-ci-' becomes '-ti-' if it is followed by a vowel written with the humanist pronunciation (sound value) (e.g. "amicicia" = amicitia). The ' $j-$-' becomes ' $-i-$ '

30 J. Harmatta, K. Szovák, I. Boronkai, L. Benkő, I. Bellus (eds.), Lexicon Latinitatis; A. Bartal, A magyarországi latinság.

31 We have chosen the well-known work of Du Cange which may have persistent orthographic rules. C. du F. Du Cange, Glossarium medice et infimce latinitatis I-X, Niort 1883-1887.

32 Our examples for the transformations can be found between double quotation mark. They either come from the first manuscript of the treaty of Passarowitz (ÖStA HHStA Staaten Abteilungen Türkei V., Varia und Collectanea: Friede v. Passarowitz, 1718 2943-2973.) or from our transcription of the witch trials of Szeged (G. Brand1, P.G. Tóth, Szegedi boszorkányperek, passim). For other examples (mostly for Hungarian letters) we used the database of the letters of the peace treaty of Szonny, see: G. Brandl, Cs. Göncö1, K. Juhász, G.E. Marton, J. Szabados, "Válogatott források," pp. 151-203. 
(e.g. "jacturam" = iacturam). ${ }^{33}$ The '-ij-' and the '-ji-' always changes to '-ii-' (e.g. "consilij" = consilii). The ' $-u$-' changes to '- $v$-' according to sound value described as humanist pronunciation (e.g. "uero" = vero). The "letter pairs," since they are rare

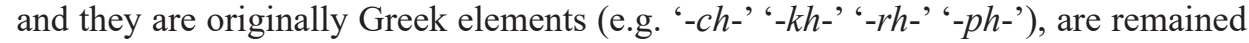
in their orthographic form (e.g. "christianos" = christianos). The ' $-z$-' according to humanist rules changes to '-s-' (e.g. "conzilium" = consilium). The '- $y$-' transcribed as ' $-i$-' in those cases where the word according to the classical form does not contain the '- $y$-'. In these words ' $-y$-' can be seen as a later change and it is not commonly used (e.g. "inclytus" = inclytus, but "pyraticus" = piraticus).

\section{Transformation of the consonants according to the guideline}

\begin{tabular}{|c|c|c|c|c|c|}
\hline Original & Transformed & Original & Transformed & Original & Transformed \\
\hline$'-\ddot{y}-'$ & '-ii-' or '-y-' & $'-k-'$ & $'-c-'$ & '-ch-' & '-ch-' \\
\hline '- $\alpha e-'$ & '-ae-' & '-ci-' & '- $t i-'[!]$ & '-kh-' & $'-k h-'$ \\
\hline '- $\propto-'$ & '-oe-' & $-j-'$ & $'-i-'$ & '-rh-' & '-rh-' \\
\hline \multirow[t]{2}{*}{$'-\ddot{w}-'$} & '-w-' or '-v-' & '-u-' & $'-v-'$ & '-ph-' & '-ph-' \\
\hline & & '-z-' & '-S-' & '-y-' & '-i-'[!] \\
\hline
\end{tabular}

Accents, diacritical marks, signs, glyphs, etc.

The different marks which are not commonly used in the humanist Latin should be deleted (including the signs, which signify the length of vowels, e.g. "sincerê" $=$ sincere, or "tütô" =tuto). Loanwords from vernacular languages rendered into Latin script in Latinised forms keep the frequently used diacritic (e.g. "bojári" = bojári).

\section{Double consonants and vowels}

In case of words which alternate between the '-ae-' and '-e-' we change to '-ae-', according to their frequency in our texts. The double consonants which are abbreviated with signs are spelt in full form with no reference (e.g. ' $-\dot{m}^{-}$' " comunis" $=\mathrm{com}$ munis), but in case of absence of the abbreviating sign, it is not necessary to add the lacking consonant (e.g. "adico" = adico instead of the classical addico).

\section{Abbreviations and acronyms (marked-unmarked)}

Those abbreviations will be unfolded that can be done unequivocally as the guideline suggests, and no note is needed for (e.g. "mjtis"= maiestatis). The uncertain abbre-

33 In the Hungarian tradition of Latin, the writing of the ' $j$ ' can be considered unique and typically Hungarian. Some of the earlier editorial guidelines suggest to keep it on the basis of that (see: I. Soós, Javaslatok, pp. 81-89). But since this guideline intend to be an international guideline and some of the scripts do not have Hungarian origin, we might think it can be uniformized to the humanist form, which is more common in modern editions. 
viations are also written in full form, but the uncertainty should be marked (e.g. "Sm" = Suam [?]). Inherent abbreviations are preserved in their common forms (e.g. "incattus" = incattus 'in causam attractus' brought into lawsuit = 'the person who has been sued' or "etc" = etc).

\section{Problems of orthography (spelling, hyphenation, capitalisation, word breaks, emphasis, punctuation) and grammar}

\section{Transcription of proper names and loanwords}

The partially Latin phrases (vernacular interlines, inscriptions, etc.) which are located in Latin texts preserve the modified linguistic features) and are transcribed in a letter-perfect transcription. Therefore, Latin words that appear in scripts in a modified Hungarian-like form (supplemented with Hungarian suffixes or prefixes even using Hungarian spelling etc. (e.g. "testimóniumát" = testimóniumát 'his testimony') are written according to a the rules of a Hungarian editorial guideline (e.g. "ratifikállya a pacifikációt" = ratifikálja a pacifikációt 'ratify the peace'). Proper names, vernacular elements, and other loanwords that cannot be found in humanist Latin, keep their letter-perfect forms, although the rules on special characters need to be applied (e.g. "Vjẅar" = Vjwar (Érsekújvár, present day Nové Zámky in Slovakia), "Budee" = Budae 'Ofen' (Buda) or "Esterhasÿ" = Esterhasy).

The description of initials, calligraphic and ornamented elements, different materials or coloured inks, etc. can be described in the footnotes, e.g. golden letters in the names of the emperors. In the main text, only the converted elements are found.

In case of proper names that are not written consistently, we signify the deviation but even the obvious slips of the pen should not be corrected. Only small letters should be changed to capitals, in order to indicate proper names (e.g. "Syrmo" = Syrmo but "syrmio" = Syrmio). Names that consist of more parts need to be written with capital initials. But words denoting ranks or titles are written with small letters (e.g. "Hungarico Aulico Cancellaria" or "palatinus Nicholaus Esterhasi"). Adjectives derived from names are also written with capital letter and treated as proper names (e.g. "milites Vjvarienses").

\section{Word separation ${ }^{34}$}

In case of compounds and word separation, we incline the separate those words which cannot be found commonly. This unifying can be done if we follow glossaries as reference points, but the common compounds should be kept (e.g. "una cum" but "priusquam").

34 In this László Glück’s instructions were followed, see above: L. Glück, Szabályzat, pp. 1-3. 


\section{Uppercase and lowercase letters}

The use of uppercase and lowercase letters is not consistent in neo-Latin texts, so we have to change it following unified rules, and modernise them to a great extent. ${ }^{35}$ Adjectives derived from proper names need to be written with capital letters, including names of institutions, geographical names, etc. as well (e.g. "Pasa Budensis" = pasa Budensis 'the Pasha of Buda'). Phrases related to divine entities are written with capital letters (e.g. "Deus," "Dominus," "Allah," "Sanctae Trinitatis" = Sancti Trinitatis 'the Holy Trinity'). Invocations are considered as full sentences, thus only the first word is written with a capital letter, punctuation is used at the end of the sentence (e.g. "Excellentissimae Domine Comes Supreme Cancellariae-Aulice" = Excellentissime domine comes supreme cancellarie aulice! 'The most excellent supreme lord courtly chancellor!'). Names of institutions that are considered proper names are written with capital letter (e.g. "Porta" = Porta 'the Sublime Porte'), as well as names of months (e.g. "Augustus" = Augustus 'August').

\section{Grammar and spelling}

Corrupted forms are indicated and explained in footnotes, and in the main text only the corrected form is given (e.g. main text: "factus sunt . . palankas." One should write into the footnote the following: "factus est . . palankas." Viz. "they were erected . . . fortifications'. Longer phrases are considered as whole sentences, therefore formulas are considered whole syntactic units (e.g. invocations, intitulations, inscriptions) and we use punctuation marks as well (e.g. "In Nomine Sanctissimae ac Individuae Trinitatis"! = In nomine Sanctissimae ac Individuae Trinitatis! 'In the name of the Holy and Undivided Trinity!'). ${ }^{36}$

\section{General notes on editorial principles and apparatus}

The guideline has a clear scientific goal, at the same time it aims to present texts to a wider audience. Based on that, the main purpose of the scientific apparatus and references is not only to mirror the text as it is, but also present information which underlines the main context and content of the source. The publication intends to keep the main text simple and clear, so the explanations should be placed in notes.

35 In the Hungarian tradition of publishing Latin sources, the usage of capitals is a manifolded issue. Some of the scholars are advocates of a complicated usage of them in order to keep the original practice more. For example, the aforementioned István Soós, among other rules, suggests that every pronoun which refers to the dignitaries (e.g. name of the emperor with a pronoun like "Nos" which mins us as a plural of majesty) should be written with capital, see: I. Soós, Javaslatok, pp. 81-89. But the issue is polemic, since such an editorial practice makes the usage of the published edition problematic. See: L. Glück, Szabályzat, pp. 1-3.

36 In case of names of deities, we use capital letters, even in case of adjective attributions if they traditionally became the part of the name as an epithet. 
Therefore, we unfold as many abbreviations as we can without remarks, in line with grammatical rules, if it is possible with letters or Arabic numbers. The external summaries or archival signings of the documents are deleted, unless they can provide important further information.

\section{Text editing}

Page breaks in the original documents are not indicated and catchwords are also deleted. Disjunctions are erased, with the intention of not making new ones. Every fifth lines is numbered to simplify the further references with bold Arabic numbers, and they are starting from one in case of every file. We do not eliminate the original syntactic units, although we segment the texts with punctuation marks based on the content and modern punctuation conventions. We keep paragraphs and coherent sections together, therefore when it is possible, we keep the titles as well. In case of documents extending over several pages, the page or folio number is indicated. Important information concerning the external part of the document is given in footnotes (e.g. date of arrival of a letter etc.)

\section{Numbers, dates and chronological signings}

The original page numbers of the manuscripts are given (e.g. [917. pag.] as well the folios (e.g. [fol. 127r.]). Abbreviated forms of numbers are given with letters (e.g. " $2^{\text {ndo" }}=$ secundo), including months if they consist abbreviation of a suffix (e.g. "9bris" = novembris). Dates in plain text are kept as such (e.g. "die vigesima prima mensis Iulii, anno millesimo septingentessimo decimo octavo" 'on the twenty-first day of July in the one thousand seven hundred and fifteenth year'). Typical parts of festivities, names of saints, etc. if they are abbreviated, changed into a complete form (e.g. "adf. S. Gii." = ad festum Sancti Georgii 'feast of Saint George'). Roman numbers are changed to Arabic numbers (e.g. "VI. Articulus" =6. Articulus ' $6{ }^{\text {th }}$ article'). Diacritical marks of the numerals are indicated according to modern English grammar (e.g. "2;" = 2). Dates are given according to the Muslim calendar, which based on the Latin alphabet, and need to be written letter-perfect form and described in footnotes. ${ }^{37}$ In case of the deficient dates we implement only the unequivocal deficiencies (e.g. " $\underline{26} "=1626) .{ }^{38}$

37 In case of transcription of Muslim dates, we might use a totally transformed form, like 'Zilhicce 4., 1013 ' is localised as 'April 23, 1605'. See this and further examples from the article written by Sándor Papp in this same volume.

38 There are certain controversies about writing of different dates in the Hungarian historiography, but as István Fazekas notes, the international standard might let to the point to simplify these problems and let the editor unfold and supplement the different forms of dates. See more: I. Fazekas, Korreferátum, pp. 77-80. 


\section{Typical abbreviations and upper and lower indexing}

Forms written in superscripts are automatically changed to normal lineage (e.g. $"$ "Sac ${ }^{\text {rme } " ~=~ S a c r a t i s s i m e) ~}$. Typical abbreviations are written without remarks (e.g. " $m$. p." = manu propria "with one's own hand' or "l. s." = locum sigilli "place of the seal'). Graphical signs, that can be written with letters are spelt out (e.g. " $\$$ " = paragraphus or "\&" =et), but every uncommon form should be described in the footnotes.

\section{Usage of the punctuation}

The punctuation marks are given following modern spelling conventions and sings not commonly used in the modern convention are deleted. Therefore the ';' or ' $:$ ' which marks the end of the sentence is changed to '. . The quotes are signed with quotation marks ' " "' '. The questions are ending with '?' and at the end of the invocation we use '!'.

\section{General signings and philological notes, references, citations}

The references are given as footnotes at the bottom of the page and marked with Arabic numbers. The philological references are significant because of the numerous drafts, transliteration, translations, copies, etc. Thus, we supplement the script with three additional information. (1.) Type of the change e.g. underlining, crossing, deletion, interpolation, replacement, etc. (2.) What is the direction of the change e.g. after, before, below, over, from the margin, etc. (3.) What is the changed passage e.g. 'principem ac dominum'.

Underlining is only signed when it has a clear function in the manuscript, so the hand wanted to highlight information which otherwise could not be emphasised. If the underlining only has not a specific function, it can be deleted. If the lining is long, we only sign the starting and ending words (e.g. underlined: 'Flandri' or e.g. underlined: 'Regiis . . . concomitanter').

In case of interpolation, if the addition or correction has a clear place, the interpolated text is simply implemented in the main text, following the style of the writer. If the interpolation is not unequivocal, it needs to be described in the footnotes (e.g. interpolated from below: 'sive Belgii').

The corrections that are made in the original script, are only marked if they are not simply slips of the pen, for example, in case of corrections of names and place-names or in additional information. Moreover, one should note the form of the correction, and in case of corrected text the previous status should be noted in the footnotes (e.g. crossed out after: 'negotii' or corrected from: 'Paulus Esterhasi').

If the editor notices a change in the appearance of the text, for example, the structure of the letters suggests a different handwriting or the colour of the ink changes etc., the difference should be described in the footnotes (e.g. different writing: 'Carolus dei gratia' or different ink: 'dux Austriae ... Kyburgi'). 
When a word or phrase need to be deleted from the main text by the editor, because of repetition or interpolation, or since a different passage is implemented from another variant, the deletion must be marked in the footnotes (e.g. deleted after: 'tituli ut in litteris plenipotentarium').

When different variants are available, one should make different amendments. If the supplementation should be done in the main text inline, one should use mark the implemented scripts in the following way: "pax et tranquillitas illa, quae per gloriosissimos $<^{a}$ amborum ${ }^{a}>$ magnorum regum." If it is a textual variant for a phrase or word, with an important difference in meaning, it should be described in the footnotes (e.g. Replacement: ${ }^{\text {a }}$ principe ac dominum ${ }^{\text {a }}$ ). In these notes the variants of the manuscripts are signed with a given mark like '-a-a_', which variants are explained in the heading with references. The external marks of the documents such as the address, date of incoming, etc. are signed in the footnotes (e.g. deleted from the cover: 'Viennae, Aprilis 27').

\section{General inline and intertextual signs}

()$=$ It's used instead of the original brackets e.g. '-//-' or '-/: :/-'. We unify it in the main text.

[]$=$ Every implementation of the editor on the manuscript(s) should be signed with link bracket (square brackets).

$[?]=$ The question mark in brackets signifies the uncertain reading and understanding of a word.

$[!]=$ The exclamation mark signifies a deliberately preserved but corrupted or uncommon form.

$[\ldots]=$ The three point signs the damage of the document or an unreadable part.

$[1]=$ The page numbers and folio numbers are given in square brackets.

$(1)=$ The different sections of the abstracts are signed in the main text in round brackets.

$\mathbf{1}=$ The bold Arabic numbers are signing the actual folio or page number of the main text. It can stand for the lineage of the text as well, where every fifth role number is given.

" $x x x "=$ For quotations and inline texts written in reported speech we use quotation marks.

' $x x x^{\prime}$ ' To mark the related passage in the footnotes and references.

$\langle x x x\rangle=$ Mark of inserts from other handwriting to implement the basic/principle text. ${ }^{\mathrm{a}} x x x^{\mathrm{a}}=$ We mark textual variants with small Latin letters written in the upper index.

s. d. = 'sine dato', in case of unknown publication date.

s. 1. = 'sine loco', in case of unknown publication place.

fol. = 'folio', those documents which are numbered only by the folio of the sheets, passages (folio) are given according to it.

r. = 'recto', = right/front side of a leaf of paper; recto folii (Lat.) 'on the right side of the leaf'. 
$\mathrm{v} .=$ 'verso', = left/back side of a leaf of paper; verso folii (Lat.) 'on the back side of the leaf'.

pag. = 'pagina', to mark the page number of the document.

e.g. = 'exempli gratia', means 'for example'.

IV. Editorial heading of the text and its abbreviations (in case of the peace treaty documents)

Example of the editorial heading of the peace treaty of Passarowitz

\begin{tabular}{|} 
Požarevac, May-July 1718 \\
PEACE NEGOTIATIONS BETWEEN THE OTTOMAN AND HABSBURG \\
EMPIRES AND THE VENETIAN REPUBLIC WITH MEDIATION OF \\
THE UNITED KINGDOM AND THE DUTCH REPUBLIC \\
I./A \\
Požarevac, July 23, 1718 \\
Pace treaty in Latin language between the Habsburg Emperor Charles VI and the \\
Ottoman Sultan Ahmed III with ratification by the British (Robert Sutton) and the \\
Dutch (Jacob Colyers) mediatory representatives and by Charles VI DOCUMENT: \\
B: ÖStA HHStA Staatenabteilungen Türkei V, Varia und Collectanea: Kt. 2. (Friede \\
v. Passarowitz 1718, Bd. 2.), pag. 943-973. EDITION: DUMONT 1731 VIII/I. pp. \\
520-524.; LITERATURE: KATONA 1806. XIX. pp. 370-392. COPIES: (1 a) \\
(2 b) F: GENERAL COLLECTION 1732 401-415 (3)
\end{tabular}

\section{Classification of the document (general number)}

One might sign the relative position of the negotiations in the timespan with Arabic numerals. This might be helpful for the latter digital or paper-based edition and for the compilation of the indexes (e.g. 1).

The title, name and date of the negotiations (time, place, date)

If the accurate place of the negotiations, where the delegations conducted the pre-discussions, is known, it is given as the place of origin, and the toponym is given in modern (contemporary) transcription (place: e.g. Požarevac). If the modern form does not generally use the Latin alphabet one should convert it, but keep all the other elements (e.g. Београд = Beograd). 
In case of the time of the conduction of the peacemaking process, the given date should embrace the whole period of the negotiations, which we only give in year and month extension (Date: e.g. May-July 1718).

Since under the title of one negotiation several documents can be found, the negotiation itself should be discussed under different titles, and just after in a broad title one should enrol the different documents due to their textual relations. In the main title (title of the negotiation) one should incorporate (in order): (1) the form of the negotiations (2) the names of the main states involved in the treaty with their role (3) name and role of the secondary states, denomination of the negotiations. (see the example in the box above: BETWEEN THE OTTOMAN AND HABSBURG EMPIRES ...).

\section{Title, date and number of the given document}

The numbering of the document should contain the number of the main document, the primer manuscript (e.g. I). Every variant which should be published of the main manuscripts (like different language versions of equal level) should be marked with capital letters. So, the Latin language version of the main manuscript will be signed with 'A' (e.g. I/A) and the Ottoman equivalent would be 'B' (e.g. I/B), and their different versions should be signed in the headings of these documents as variants.

This refers to the name of the place of origin, which in case of postal items would be identical as the place of consignment (e.g. Požarevac). If the place of origin cannot be designated (it is dubious or may not prove that it is the same as the place of the negotiations), it should be signed as s. 1. = 'sine loco'.

The date of the formation of the given document in ' $m m m ~ d d$, yyyy' format, in which the name of the month is written with letters. If the document cannot be dated, it should be signed s. d. = 'sine dato'. In case of dubious dating only the year is signed (if it is known) or in case of valid presumption the date should be signed with [?] after the date (date: July 23, 1718; dubious date: July 23, 1718 [?]).

The title describes the exact document, which need to incorporate: (1) type of negotiation, (2) language, (3) concerned main participants with official name and titles and the exact role in the discussions, (4) secondary participants with their official names and titles and their exact role (see the example in the box above: Peace treaty in Latin language ....).

\section{Diplomatic classification of the document (main manuscript)}

The primary script (fundamental script, primer manuscript, etc.) for the transcription and translation must be signed differently from other texts. In the heading we highlight it, since it will be the primary text for implementing and editing (e.g. DOCUMENT). Usually it is written on an authentic language, mainly Ottoman and Latin, and it is the final treaty or the closest variant of the definitive ratified copy of a treaty.

With the capital letters of the alphabet we sign the different forms of this primary text based on the attributions of the documents (draft, copy, translation, etc). In case 
of various variants, these letters can be useful to describe the other manuscripts as well. (A) In general, it refers to an original ratified manuscript, which has been issued in an authentic, ornamented charter (diploma).$^{39}$ (B) It sings the authentic and original contemporary copies. ${ }^{40}(\mathbf{C})$ It marks the contemporary draft versions, since during peace making process many variants existed..$^{41}$ (D) It refers to contemporary translations, since many of the official draft versions were translated for private use for the members of the diplomatic apparatus in their native languages (e.g. German or Hungarian), or intermediary languages (e.g. Italian). ${ }^{42}$ (E) It signs the contemporary printed editions. ${ }^{43}$ (F) It refers to those early print copies which has not been published contemporarily but can be considered early and functional editions. ${ }^{44}$ (G) It refers to early bibliographical translation. ${ }^{45}$

\section{Archival record and reference}

In case of giving the location of the exact file, one should use an abbreviated archival reference. In this, the name of the archive is given in the original language in abbreviated form with capitals, then the exact reference of the file is given with the full name of section or subsection (fond) with the precise archival storage unit (box, bundle, etc.) and date if it is noted (see in the box above). If the form of reference

39 However, the Latin originals of the peace treaties, because of the mutual change of documents, would have been in Constantinople, but as to our present knowledge they have been destroyed.

40 The closest standing duplicates to the original scripts, like the private versions of envoys or different deputies, sometimes copied into diaries or circular copies sent to bailiffs ('ispán') or captains.

41 Mostly, they have been compiled during the period of negotiations or exactly on meetings, but the honorific and ornamental formulas are not incorporated into these documents. Regularly they are the copies of the peace commissaries and can be found in their personal heritage.

42 It happened mostly because of the lack of knowledge or because they wanted or had sent it to others.

43 In order to inform the general public, copies in contemporary newspapers or in other printed materials were common (e.g. leaflets, copies like the Wienerisches Diarium (Wiener Zeitung), etc.). The Wieneriches Diarium was established in 1703 and was a supporter of the Habsburg Court and it was under the Court's influence. The newspaper is still published, but from 1780 under the title of Wiener Zeitung. In the database of the Österreichische Nationalbibliothek (Austrian National Library (in the following: ÖNB) (called ANNO = Austrian Newspaper Online) all the early issues can be found for free, with general descriptions. See: ANNO, http://anno.onb.ac.at/cgi-content/anno?aid=wrz [accessed: September 28, 2019].

44 Such as copies in jurisdictional collections or in books assembled for internal usage of chancelleries or governmental authorities, like the collection of the Foreign Office. For example, the four-volume work of Samuel Whately were offer to the prime minister sir Robert Walpole and for the renewed edition the author could have used documents from the archive of the parliament. See: S. Whatley, A General Collection of Treatys, Declarations of war, Manifestos, and Other Publick Papers, Relating to Peace and war I-IV, London 1732. Especially see: pp. iv-xxxiii.

45 Usually these are copies from early books and prints, but translated into other languages, like Italian, Hungarian or German. Sometimes only summaries of the longer original Latin. See: F.W. Ghillány, Diplomatisches Handbuch: Sammlungen der wichtigsten europäischen Friedensschlüsse, Congreßacten und sonstigen Staatsurkunden vom Westphälischen Frieden bis auf die neueste Zeit; mit kurzen geschichtlichen Einleitungen II., Nordlingen 1855. Especially see: pp. 196-198, 210-223. 
needs to be changed, because of different archival forms, it can be done in order to have the opportunity for retrieval. In case of errors in the references one should use exclamation mark (e.g. [!]), but the wrong forms should be kept because of the attainability. The number of pages and folios should be kept as in the original. In case of error, the problem is signed, but the form should be kept.

\section{Literary and printed references}

The first digital or paper-based edition of the fundamental texts should be noted here, those which copied this edition should not be signed (modern edition e.g. EDITION:). In case of paper-based editions a short bibliographical reference is given (author's family name, year, page number), and only in the end of the work should be the long reference given. If it is possible, the earliest unique editions should be indicated, although the ones which incorporate new and relevant pieces of information should be marked. So, the works of Dumont is given, ${ }^{46}$ since the scholar used unknown archival sources, from the Österreichisches Staatsarchiv (Austrian State Archives, in the following: ÖStA), and it implies new unique archival data. On the other hand, the works of István Katona are not signed only if the bibliographical source is not given and because of that we assume that the script came from a contemporary handwritten document. ${ }^{47}$

The modern scientific literature concerns primary text's manuscript or textual content (does not relate to the historical background). In case of paper-based editions the bibliographical data should be given in short forms (author's family name, year, page number) (Modern literature, e.g. LITERATURE:).

\section{Duplicates and copies}

In case of different duplicates, the Arabic numbers should be used (e.g.: (1)) and the diplomatic classification should be given with capitals (e.g. F). If more than one manuscript belongs to one duplicate family, it should be signed with the small letters of the Latin alphabet (e.g. (2 a)). Therefore, the English versions are signed (e.g. $(2 \mathrm{~b}))$ in case of the different versions of the documents of the peace treaty of Passarowitz (data of copies, e.g. COPIES: (2) F: GENERAL COLLECTION 1732 pp. 401-415.).

\section{Problems of translation and the summary ('regesta')}

In a future edition one might give a translation and an abstract of the transcribed text as well. In case of translations, we might follow modern language forms in Eng-

46 J. Dumont, Corps universel diplomatique du droit des gens I-VIII, Amsterdam 1726-1734.

47 The famous work of Katona generally uses the work of Dumont in case of Ottoman-Habsburg peace treaties and simply copy their text from that work. S. Katona, Historia Critica Regum Hungariae I-XLII, Pest 1779-1817. In case of the treaty of Passarowitz, see: S. Katona, Historia, XIX, pp. 370-392. 
lish as well as in Hungarian (or in other languages), since one might facilitate a broad and general usage, and comprehensibility in the same way. Moreover, one may see the identicality of the content, though the syntactical level or the usage of vocabulary might be altered. Therefore, the punctuation and structure of the sentences might be transformed in order to emphasise the exact meaning. Moreover, if a script already has a contemporary translation, one might use it, but not for modernising it, just to have a more definite interpretation of the original. So the translations in the heads of the files are generally used for translations but not to be published or modernised.

\section{Structural unification}

For the sake of providing unified translation to these typologically similar texts, an apparatus of translation should be evolved, in which some of the following phrases should be translated similarly: (1) toponyms, (2) proper names, (3) formulas and returning phrases, (4) uniformed usage of fixed notions (especially in case of legal terms).

\section{Modernisation and problems of translation}

A completely modern translation implies that the syntactical structure of the translation might be changed according to the meaning. Therefore, the different participial structures can be altered to predicates or be supplemented, the lexical problems or disambiguates can be modernised and the different literary figures etc. can be simplified considering the general meaning of the text.

In case of the transcriptions of personal names, one might take the providential language form of the given name authoritative. Therefore, the family name is provided in a letter-perfect transcription but in case of the first name, the language of origin is normative (only in translation and abstract). The different Latinised and Germanised forms are not published (e.g. "Michael Talmann" = Michael Tallmann but "Antonius Eszterházi" = Antal Eszterházi, in the translation (even in Hungarian) "Robertus Sutton" = Robert Sutton and not Sutton Róbert).

The toponyms are translated in a modernised language form. The names of different settlements etc. can be given according to the present form (concerning the given country's public administration), or with regards of its historical contemporary usage. If the geographical term cannot be determined, it needs to be kept in a letter-perfect transcription. Moreover, if the notion or term has a cross border reference (like rivers) or has a traditional form in a given language, it can be kept on the basis of contemporary use for the better understanding based on the choice of the editor, but must follow the contemporary usage of the word (e.g. "Danubius" in Hungarian translation 'Duna', in English translation 'Danube', but "Orsava" = Orşova or Orsova) based on the translators' choice, and the usage of the localising language ("Constantinopolis" = Konstantinápoly or Constantinople, "Griechischweisenburg" = in Hungarian 
Nándorfehérvár or Belgrád, in English Belgrade, but can be as well Beograd, but not transcribed from Београд). ${ }^{48}$

Insofar, whenever the usage of anachronistic notion is inevitable, thus the modern form of the notion should be given in order to have an accurate meaning (e.g. "unitarum Belgii provinciarum" = 'united states of Belgium' viz. "Dutch Republic (United Provinces of the Netherlands)").

\section{Sample of translations}

Latin script

\section{Articulus tertius}

Cum a Drina fluvio usque ad Unnam in utraque ripa fluvii Savi sitae, sive apertae sive occlusae arces et palancae Romanorum imperatoris milite munitae sint, cum antiquis suis territoriis iuxta fundamentum pacis in eiusdem Sacratissimae Caesareae $<^{\mathrm{a}}$ Regiaeque ${ }^{\mathrm{a}}>$ Maiestatis potestate permanento, quare etiam integer fluvius Savus cum suis ripis ad eandem pertinet.

\section{English translation}

\section{Third Article}

Since places situate on both sides of the river Sava from the Drina till the Una rivers, either unprotected or fortified strongholds or castles were circumvallated by the Roman Emperor's troops, therefore (viz. these strongholds) should remain in the authority of his sacred imperial and royal majesty (viz. Emperor) with their old territories (viz. endowment), according to the preliminaries of the peace, as the Sava, with its shores, should belong to him.

\section{Regesta (summary)}

The abstract is segmented into different parts and it is marked before the signified text. The sections are signed in the main text as well, therefore the same Arabic number should be used in both texts (e.g. (1)). The abstract come after the heading of the script, its written with italics and there are no paragraphs in it. The sections of the abstracts are given based on the customary palaeographical specificities. Moreover,

48 The transcription and modernisation of toponyms can be considered a highly problematic issue, since the contemporary usage of the names of the different places e.g. cities went through a contested transformation and in many cases even the contemporary use is not homogenous. The fully modernised forms would disregard this historical process. So to have a common ground the MTA-SZTE Research Group of the Ottoman Age agreed on a system which is standing closer to the contemporary use, but not neglecting the editor's choice. Other authors also choose this way, see: D. Kołodziejczyk, The Crimean Khanate, pp. XXX-XXXV. 
in case the recurrent formulas, we only give the type of formula. (e.g. (3): Intitulation). We specify the different articles of the peace treaties in separate sections and after the section number we give the article number and the theme of its topic as well.

\section{English abstract of treaty of Passarowitz}

(1) Intitulation: Titles of the Roman Emperor. (2) Inscritpion: To all persons whom it may concern. (3) Invocation: Christian catholic prayer. . . (6) 1. article: About the borders of Moldavia, Wallachia and Transylvania. (7) 2. article: The borders of the countries in the lower Danube region.... (30) Confirmation: Confirmation and corroboration by the Habsburg Emperor and his chancellor. (31) Subscription: Signatures of the emperor and his chancellor. . . (35) Subscription: Signatures of the British envoys.

\section{Description of the appendices}

The indices collect all the various forms of a certain notion's appearances in the main texts under one headword. The headword has been generally described but all the different forms are given by their reference of appearance. In case of citation or give a reference to certain appearance of words or phrases, we refer to the exact document where the described word can be found. The data consist of elements from the heading: (1) Number of the negotiations, (2) The date of the negotiations, (3) Number of the document. Naturally one document can have many references by appearances of different words (e.g. 1/1718/I./A).

\section{Index of toponyms:}

Schachak (sr. Čačak) [Sr.]

Maros folyó - (h. Maros r. Mureș) [Hu. - Ro.] - Marusinum; Maros; Maros parton $=1 / 1718 / \mathrm{I} . / \mathrm{A}$.

Index of persons:

Charles the IV. $>$ Habsburg emperor $>$ Carolus, Carolus Sextus $=1 / 1718 / \mathrm{I} . / \mathrm{A}$. Eszterházy Miklós> Hungarian palatine> Nicholaus Esterhas; palitnus Esterhasy; Galánthai gróf Esterházy Miklós = 1/1718/I./A. 


\title{
BIBLIOGRAPHY
}

\author{
Primary Sources
}

ÖStA HHStA Staatenabteilungen Türkei V, Varia und Collectanea: Kt. 2. (Friede v. Passarowitz 1718, Bd. 2.), pag. 943-973.

\section{Primary Sources Published}

Balogh B., Nagybányai boszorkányperek, Budapest 1997.

Bessenyei J., Kiss A., Pál-Antal S., Tóth P.G., A magyarországi boszorkányság forrásai I-IV, Budapest 1997-2005.

Brandl G., Tóth G.P., Szegedi boszorkányperek 1726-1744, Budapest 2016.

Csáky I., Esztergom vármegye címereslevele, Nyíregyháza 2011.

Dumont J., Corps universel diplomatique du droit des gens I-VIII, Amsterdam 1726-1734.

Ghillány F. W., Diplomatisches Handbuch: Sammlungen der wichtigsten europäischen Friedensschlüsse, Congreßacten und sonstigen Staatsurkunden vom Westphälischen Frieden bis auf die neueste Zeit; mit kurzen geschichtlichen Einleitungen II, Nordlingen 1855.

Hagenthum E., Segesvári boszorkányperek, Budapest 2010.

Katona S., Historia Critica Regum Hungariae I-XLII, Pest 1779-1817.

Kołodziejczyk D., Ottoman-Polish Diplomatic Relations (15 th $-18^{\text {th }}$ Century). An Annotated Edition of 'Ahdnames and Other Documents, Leiden, Boston, Köln 2000.

Kołodziejczyk D., The Crimean Khanate and Poland-Lithuania. International Diplomacy on the European Periphery (15 $-18^{\text {th }}$ Century). A Study of Peace Treaties Followed by Annotated Documents, Boston 2011.

Papp S., Die Verleihungs-, Bekräftigungs- und Vertragsurkunden der Osmanen für Ungarn und Siebenbürgen. Eine quellenkritische Untersuchung, Wien 2003.

Soós I., VI. (III.) Károly német-római császár, magyar és cseh király adománylevele a szentgotthárdi ciszterci apátság visszaállitásáról és a heiligenkreuzi ciszterci apátsággal történő egyesitéséröl, 1734, Szentgotthárd 2016.

Theunissen H.P.A., "Ottoman Venetian Diplomatics: the 'Ahd-names. The Historical Background and the Development of a Category of Political-Commercial Instruments together with an Annotated Edition of Corpus of Relevant Documents," Electronic Journal of Oriental Studies 1998, no. 2, pp. 1-698.

Tóth G.P., Németh I., Soproni boszorkányperek, Budapest 2010.

Tóth G.P., Pakó L., Kiss A., Kolozsvári boszorkányperek 1564-1743, Budapest 2014.

Whatley S., A General Collection of Treatys, Declarations of war, Manifestos, and Other Publick Papers, Relating to Peace and war I-IV, London 1732.

\section{Literature}

Bartal A., A magyarországi latinság szótára, Budapest 1901.

Benda K., “A Magyar Országgyülési Emlékek sorozat 1607-1790 közti részének szerkesztési és forrásközlési szabályzata,” Századok 1974, no. 2, pp. 436-475. 
Benda K., "A magyar történeti forráskiadás múltja és mai helyzete. I. rész," Levéltári Közlemények 1979, no. 2, pp. 163-173.

Benda K., “A magyar történeti forráskiadás múltja és mai helyzete. II. Rész," Levéltári Közlemények 1982, no. 2, pp. 201-205.

Benda K., A történeti forráskiadványok helyzete Magyarországon. Levéltár és nyilvánosság. Levéltári Napok 1992, Budapest 1993.

Bene S., Békés E., "Módszertani ajánlás a Bibliotheca Scriptorum Medii Recentisque Aevorum új sorozatának (Series Nova) szöveggondozásához," Irodalomtörténeti Közlemények 2014, no. 1, pp. 698-713.

Brandl G., Göncöl Cs., Juhász K., Marton G.E., Szabados J., “Kommunikáció és híráramlás az 1627. évi szőnyi békekötés alkalmával a Habsburg oldal tárgyalási stratégiájának tükrében," Aetas 2018, no. 4, pp. 108-124.

Brandl G., Göncöl Cs., Juhász K., Marton G.E., Szabados J., "Válogatott források az 1627. évi szőnyi békeszerződés történetéhez," Lymbus 2017, no. 1, pp. 153-203.

Du Cange C. du F., Glossarium mediae et infimae latinitatis I-X, Niort 1883-1887.

"Empfehlungen zur Edition frühneuzeitlicher Texte," Jahrbuch der historischen Forschung in der Bundesrepublik Deutschland 1980, pp. 85-96.

Fazekas I., "Korreferátum Oborni Teréz előadásához," Fons 2000, no. 1, pp. 77-80.

Finály H., A latin nyelv szótára, Budapest 1884.

Ford P., Bloemendal J., Fantazzi Ch.E., Brill's Encyclopaedia of the Neo-Latin World, Leiden 2014.

"Forrráskiadási szabályzatok (újraközlések)," Studium Füzetek 2000, no. 1.

Gáldi L., Magyar szótárirodalom a felvilágosodás korában és a reformkorban, Budapest 1957.

Harmatta J., Szovák K., Boronkai I., Benkő L., Bellus I. (eds.), Lexicon Latinitatis Medii Aevi Hungariae I-VI, Budapest 1982-2017.

Hóman B., A forráskutatás és a forráskritika története, Budapest 1925.

Horváth Z., "Editio Multiplex - Kora újkori források kiadása" [in:] Docere et movere: Bölcsészet- és társadalomtudományi tanulmányok a Miskolci Egyetem Bölcsészettudományi Kar 20 éves jubileumára, eds. M.I. Kovács, É. Gyulai, T. Porkoláb, G. Biczó, Miskolc 2012.

Kosáry D., Kulcsár K., Szakály O., Bevezetés Magyarország történetének forrásaiba és irodalmába I. Általános rész, 3. köt., Megyei levéltárak és forrásközlések, Általános rész 4. köt., Városi, mezövárosi és községi levéltárak és forrásközlések, Budapest 2008-2015.

Jakó Zs., Manulescu R., A latin írás története, Budapest 1987.

Mihalik B., "Bél Mátyás Notitiájának kiadása - a forráskiadás 21. századi útjai," Történelmi Szemle 2013, no. 2, pp. 341-349.

Oborni T., A kora újkori latin nyelvü forrásszövegek kiadásáról.

Papp S., "Az Oszmán Birodalom, a Magyar Királyság és a Habsburg Monarchia kapcsolattörténete a békekötések tükrében (vázlat és adatbázis)," Aetas 2018, no. 4, pp. 86-99.

Papp S., “A pozsareváci békekötés és a magyarok,” Aetas 2018, no. 4, pp. 5-19.

Péter L. (ed.), Irodalmi szövegek kritikai kiadásának szabályzata, Budapest 1988.

Petritsch E.D., "Dissimulieren in den habsburgisch-osmanischen Friedens- und Waffenstillstandsvertragen (16-17. Jahrhundert): Differenzen und Divergenzen" [in:] Frieden und Konfliktmanagement in interkulturellen Räumen: das Osmanische Reich und die Habsburgermonarchie in der Frühen Neuzeit, eds. A. Strohmeyer, N. Spannenberger, Stuttgart 2013.

Soós I., Javaslatok az újkori magyarországi latin és német nyelvü források kiadására, pp. 81-89. 
Strohmeyer A., "Wahrnehmungen des Fremden: Differenzierungen von Diplomaten im 16. und 17. Jahrhundert: Forschungsstand - Eträge - Perspektiven" [in:] Wahrnehmungen des Fremden: Differenzierungen von Diplomaten im 16. und 17. Jahrhundert. (Schriftreihe der Vereinigung zur Erforschung der Neueren Geschichte. e. V., 31.), eds. M. Rohrschneider, A. Strohmeyer, Münster 2007, pp. 1-50.

Szamota I., Zolnay Gy., Magyar oklevél-szótár, Budapest 1902-1906.

Tringli I., Középkori oklevelek kiadásának problémái, pp. 7-40.

Tóth G., Bél Mátyás „Notitia Hungariae novae...” címü müvének keletkezéstörténete és kéziratainak ismertetése, (manuscript) Budapest 2007.

\section{Articles in press}

Bara P., Latin szövegek átírása és jegyzetelése (tervezet) (manuscript), Szeged 2018.

Glück L., Latin szövegkiadási szabályok (manuscript), Budapest 2017. 